\title{
A jövedelmi helyzet, az élettel való elégedettség és a környezeti terhelés összefüggései hazánk régióiban
}

\author{
Correlations between Income Position, \\ Satisfaction with Life and the Environmental \\ Load in Various Regions in Hungary
}

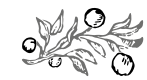

Összefoglalás

Az Easterlin-paradoxon szerint bár egy adott országban a gazdagabbak általában elégedettebbek az életükkel, és boldogabbnak mondják magukat a szegényebbeknél, de a gazdasági növekedés nem vagy nem szükségszerúen korrelál az emberek boldogságérzetével. Napjainkban egyre több tudományos kutatás foglalkozik az anyagi jólét és a szubjektív jóllét témakörével, összefüggéseinek vizsgálatával. E tanulmány arra tett kísérletet a KSH területi adatai alapján, hogy hazánk régióiban a lakosság jövedelmi helyzetének és az élettel való elégedettségének alakulását bemutassa, valamint azok kapcsolatát feltárja. A megvizsgált adatok ismeretében rangsort állít fel annak érdekében, hogy össze lehessen vetni az egyes régiók GDP-jének és jövedelmi helyzetének alakulását a lakosság elégedettségével.

Journal of Economic Literature (JEL) kódok): I31, O10, R11

Kulcsszavak: jövedelem, GDP, elégedettség, környezeti terhelés

Kiss Lívia Benita, doktorandusz, Pannon Egyetem, Gazdálkodás- és Szervezéstudományok Doktori Iskola (kiss.liva.benita@georgikon.hu). 
Kiss Lívia Benita: A jövedelmi helyzet, az élettel való elégedettség és a környezeti...

\section{Summary}

According to the Easterlin Paradox, there is no correlation between the level of economic development in a society and the overall happiness of its citizens. Satisfaction with life increases with the average income but only up to a point - beyond that the gain in happiness declines. Currently, an increasing number of research projects deal with the correlation between material welfare and subjective well-being. Based on the regional data of Central Statistics Office of Hungary, this study seeks to demonstrate changes in the income and satisfaction of the population. A hierarchy is established to enable comparison between changes in regional GDP and income and the satisfaction of the population.

Journal of Economic Literature (JEL) codes: I31, O10, R11

Keywords: incomes, GDP, satisfaction, environmental load

\section{BEVEZETÉS}

Napjainkban egyre több tudományos kutatás foglalkozik az anyagi jólét és a szubjektív jóllét témakörével, összefüggéseinek vizsgálatával. Többekben felmerült már a kérdés: egy ország lakosságának általános boldogsága alapvetốn az anyagi jólét és a magas életszínvonal függvénye lenne? Fromann (2011) szerint a fogyasztói társadalom azon alapvetése, mely szerint egy ország gazdaságának és polgárai jólétének növekedése egyben boldogságuk, szubjektív jóllétük növekedésével is jár, 1974-ben tudományosan megdôlni látszott. Az utóbbi évtizedekben egyre nyilvánvalóbbá vált, hogy a gazdasági fejlôdés nincs feltétlenül szinkronban a társadalmi folyamatokkal és az életminôség emelkedésével. Easterlin 1974-ben publikált kutatási eredményei ugyanis arra a meglepố jelenségre hívták fel a figyelmet, hogy annak ellenére, miszerint egy adott országban a gazdagabbak általában elégedettebbek az életükkel, boldogabbnak mondják magukat a szegényebbeknél, a gazdasági növekedés nem vagy nem szükségszerúen korrelál az emberek boldogságérzetével. Easterlin azt az álláspontot képviseli, hogy az anyagi javakban mért növekedés és a szubjektív jóllét között nincs oksági kapcsolat, hanem legfeljebb együttjárásról beszélhetünk.

Tanulmányom célja az volt, hogy egy olyan elemzést készítsek, mely az anyagi jólét, a szubjektív jóllét és a környezeti terhelés mérésére szolgáló indikátorok alakulását kíséri figyelemmel, valamint azok kapcsolatának feltárására irányul, szekunder területi adatok felhasználásával, hazánk hét tervezési-statisztikai régiójára nézve. Az elemzés idôintervalluma szúk, mert a KSH csak az utóbbi néhány évre készített regionális felmérést az élettel való általános elégedettség alakulásáról. 


\section{SZAKIRODALMI ÁTTEKINTÉS}

A jólét fogalma újra elootérbe került napjaink társadalmainak értékelésekor, legyen szó egy ország, egy régió vagy egy kistérség jólétérôl (Gébert, 2012), a jelen tanulmány esetében régiókról. A jólét definiálásával, változásainak megragadásával és mérésével kapcsolatos szakirodalom nagyon sokrétú, számos dimenzióval és indikátorral írható le. A jólét fogalma alatt a következókben a jelenleg is uralkodó fogyasztói társadalomban tapasztalható pénzügyi bôséget, anyagi javakban és kizárólag pénzért kapható szolgáltatásokban való gazdagságot értem.

A szubjektív jóllét vizsgálata arról szolgáltat információkat, hogy az emberek miként élik meg mindennapjaikat, hogyan érzik magukat (KSH, 2016). A szubjektív jóllét fogalmát, mutatóit élesen elkülöníthetjük az életminôség objektív mutatóitól. Az objektív mutatók egy objektív nézôpontból értékelik az egyének helyzetét, függetlenül azok értékeitôl és preferenciáitól, míg a jóllét szubjektív mutatói az egyéni preferenciákat, vágyakat, normákat tükrözve mérik az életminôséget (Diener et al., 2009; Hajdu, 2015). A szubjektív jóllét vizsgálatakor tehát az egyén megélt életminôségére koncentrálunk, azaz az egyén mentális egészségét, érzelmi állapotát, életelégedettségét mérjük kvantitatív társadalomstatisztikai módszerekkel. Nordenfelt (1993) szerint az életminôség lényegében a boldogsággal azonos. Hétköznapi értelemben az élettel való elégedettség, illetve elégedetlenség mértékeként lehet leginkább meghatározni.

A jóllétet leíró sokdimenziós indikátorrendszerek fejlôdésében meghatározóak a Stiglitz-bizottság (Sen és Fitoussi közremúködésével) 2009-ben publikált munkái. Az OECD (2013) által kidolgozott indikátorrendszer a legismertebb és legelterjedtebb, amelynek nyilvánvaló célja a nemzetközi összehasonlítás. Eurostat 2013-ban az SILC (Statistics on Income and Living Conditions) lakossági adatfelvételébe a szubjektív jóllét mérésére szolgáló modult épített be (KSH, 2014c).

Az empirikus elemzések leggyakrabban olyan indikátorát használják a szubjektív jóllétnek, ami egyetlen kérdéssel próbálja mérni a fogalmat. A három leggyakoribb kérdéstípus a boldogságra, az élettel való elégedettségre kérdez rá, valamint a Cantril-féle 9 fokú létraskála segítségével a lehetô legjobb és legrosszabb élethez viszonyítva végzi az életminôség értékelését (Hajdu, 2015). A boldogságot inkább egyfajta affektív indikátornak tekintik, amit az éppen aktuális érzelmi állapotok és a szabadságérzet jelentôsen meghatároz, míg a Cantril-létrával mért elégedettség inkább kognitív indikátorként írható le, erôsebben kötôdik a materiális, azaz anyagi jóléthez (Diener et al., 2010). Az élettel való elégedettség a boldogság és a Cantril-létra-féle életminôség vizsgálatára irányuló mutató között helyezkedik el, de inkább a Cantril-létrához hasonló jellegú. Hasonlóan gondolkodott Scitovsky (1990) is, aki különbséget tett a komfort és az öröm között. A komfortérzet, azaz elégedettség az optimális aktivációs szinthez közeli állapot, míg az öröm, vagyis a boldogság az optimális aktivációs szint felé történô elmozdulással jár együtt. 
Kiss Livia Benita: A jövedelmi helyzet, az élettel való elégedettség és a környezeti...

\section{A jövedelem és az elégedettség kapcsolata}

Hajdu (2015) szerint a jövedelem elégedettségnövelô hatása az egyik legtöbbet elemzett kérdés a szubjektív jólléttel foglalkozó szakirodalomban. Easterlin (1973; 1974; 1995) mutatott rá arra, hogy az egyéni keresztmetszeti adatokon pozitív irányú a jövedelem és a szubjektív jóllét kapcsolata. Ugyanakkor az 1950-es évek második felében a növekvő egy fơre jutó nemzeti jövedelem ellenére a gazdaságilag fejlett országokban az átlagos elégedettség szintje nem változott. Ez a megfigyelés Easterlin-paradoxon néven vált híressé (Hajdu-Hajdu, 2013). A jelenségnek az egyik leggyakrabban idézett példája az Egyesült Államok, ahol 1946 és 1991 között az egy fóre jutó anyagi jólét GDP-ben mérve a többszörösére nőtt, ugyanakkor ezzel szemben az átlagos boldogság csökkent, amit egy háromfokú skálán mértek (Frey-Stutzer, 2002). Hasonló, konstans szubjektív jóllétet figyeltek meg több fejlett országban is, például Nagy-Britanniában, Franciaországban és Németországban is (Blanchflower-Oswald, 2004; Clark et al., 2008). Stevenson és Wolfers (2008) például Japán esetében meggyôzóen cáfolta ezt az állítást, a jövedelem és az átlagos boldogság közötti enyhe pozitív összefüggés kimutatásával, más esetekben - például az Egyesült Államok tekintetében - a korábbiakkal megegyezô eredményre jutott. A paradoxon érvényességét tovább erôsítik EasterlinAngelescu (2009), Easterlin et al. (2010), illetve Easterlin (2013) tanulmányai is, amelyek azt mutatják, hogy az egyes országokban mért jövedelem és elégedettség közötti pozitív irányú időbeli kapcsolat inkább kivételnek tekinthetô. Sacks et al. (2012) széles körú adatbázist állított össze a hat fố országos felmérés ötvözésével. Easterlin állításaival szemben megállapították, hogy a gazdasági növekedés és a boldogság közötti pozitív kapcsolat a kombinált adatokban egyértelmú, még a hosszabb idôtartamokra is. Veenhoven és Vergunst (2013) hasonló elemzést végeztek, és arra a következtetésre jutottak, hogy a gazdasági növekedés hosszú távon is pozitívan kapcsolódik a szubjektív jóléthez. Végül kijelentették, hogy az Easterlin-paradoxon egy „Easterlin-illúzió”.

Easterlin megállapításait tehát többen alátámasztották, ugyanakkor mások meg is cáfolták. A kritikusok szerint hosszabb távon is van kapcsolat a boldogság és a jövedelem között, méghozzá ugyanúgy pozitív irányú. A gazdasági helyzet és a szubjektív jóllét között igenis van ok-okozati összefüggés, méghozzá szoros korrelációval, valamint nincs olyan jövedelmi határ, amely felett gyengülne az oksági kapcsolat erôssége. Easterlin késôbbi vizsgálatai, reflexiói és kutatási elemzései azonban újra és újra megerôsítették az eredeti állítását (Fromann, 2011).

A jólét és az elégedettség közötti kapcsolat egyik magyarázata szerint az anyagi helyzet javulása olyan alapvetô szükségletek kielégítését teszik lehetôvé, mint a megfelelố lakóhely vagy a rendszeres étkezés (Diener et al., 2010). Ennek megfelelően a jövedelem növekedése az alapvetô szükségletek kielégítése révén a szubjektív jóllét emelkedésével jár együtt, azonban ezután már csak kisebb hatása érvényesül. Ugyanakkor elképzelhetô az is, hogy a materiális javak birtoklása iránti vágy tanult. Azok esetében, akik kevésbé vágynak az ilyenfajta anyagi értékekre, alacsony jövedelem mellett is elérik az elégedettség magasabb fokát. A materialisták számára ennek a szintnek az eléréséhez jelentôsebb vagyon és fogyasztás szükségeltetik. Hasonló következtetésre 
jutottak azok a tanulmányok (Boyce-Wood, 2011; Budria-Ferrer-i-Carbonell, 2012) is, amelyek arra mutattak rá, hogy az egyének személyiségvonásai szignifikáns mértékben befolyásolják a jövedelem határhasznát. Tehát a jövedelem nem növeli korlátlanul a jóllétet, nem vezet minden esetben nagyobb elégedettséghez. A jövedelem és az elégedettség közötti kapcsolat megfelel a csökkenố határhaszon elméletének, hiszen konkáv formájú (Layard et al., 2008).

\section{EREDMÉNYEK}

\section{A társadalmi haladás mutatószámai}

Az egy fốre jutó GDP, a jövedelem és az élettel való elégedettség vizsgálata elôtt a társadalmi haladás egyes mutatószámait - a várható egészséges élettartamot, a háztartás-összetételt és a lakáshasználatot - is tanulmányoztam. Ezek a mutatók szoros kapcsolatban állnak az egyes régiók lakosságának jövedelmi helyzetével, valamint hatással vannak az élettel való elégedettségükre is. A várható átlagos élettartam mutatója közvetett módon szintetikus indikátora a lakosság egészségi állapotának, életmódjának, életkörülményeinek, az egészségügyi ellátórendszer fejlettségének és a környezet állapotának, amelyek a halandósági viszonyok legfontosabb tényezôi. A Közép-Magyarország (62,9 év), a Nyugat-Dunántúl (62,2 év) és a Közép-Dunántúl (59,8 év) régiókban a legmagasabb a várható élettartam, míg a legalacsonyabb a Dél-Alföld (57,75 év), a Dél-Dunántúl (56,6 év) és az Észak-Alföld (56,15 év) régiójában 2016-ban. Minden régióban nôtt 2011-hez képest 2016-ra a mutató értéke. A legjelentôsebb várható élettartam-növekedés (2,75 év) az Észak-Alföldön volt, de így 6,3 évvel marad el Közép-Magyarországtól.

A háztartás-összetétel tekintetében az egycsaládos, a többcsaládos és az egyszemélyes háztartások arányát vizsgáltam meg az egyes régiókban. Az egycsaládos háztartások (egy család alkotta háztartások) aránya Közép-Magyarországon (30,3\%), az Észak-Alföldön (14,9\%) és Dél-Alföldön (13\%) a legmagasabb, míg a Közép-Dunántúlon (10,9\%), Nyugat-Dunántúlon $(10,2 \%)$ és Dél-Dunántúlon $(9,2 \%)$ a legalacsonyabb 2016-ban. Az egycsaládos háztartások aránya 2011-hez képest a Közép-Magyarország és a Nyugat-Dunántúl régiók kivételével mindenhol csökkent. A mutató értéke - mivel e csoport alkotja a családot magukban foglaló háztartások túlnyomó többségét - utal a családnak a társadalomban elfoglalt helyzetére is. A többcsaládos háztartások (két vagy több családból álló háztartások, melyek közös háztartást vezetnek) aránya Közép-Magyarországon (25\%), Észak-Alföldön (16\%) és Észak-Magyarországon (12,6\%) a legmagasabb, míg Dél-Dunántúlon (11,2\%), Nyugat-Dunántúlon (11,8\%) és Dél-Alföldön (10,1\%) a legalacsonyabb 2016-ban. A mutató 2011-hez képest az Észak-Alföld és a Dél-Alföld kivételével minden régióban csökkent. A mutató értékének csökkenése a többgenerációs háztartások felbomlására, az egyenes ági rokonsági kapcsolatban élő családok együttélésének a visszaszorulására utal. Az egyszemélyes háztartások (egy személy alkotta háztartások) aránya Közép-Magyarországon (36,4\%), Dél-Alföldön $(13,7 \%)$ és Észak-Alföldön (12,4\%) a legmagasabb, míg a Közép-Dunántúlon (9,3\%), 
Kiss Lívia Benita: A jövedelmi helyzet, az élettel való elégedettség és a környezeti...

Nyugat-Dunántúlon (8,9\%) és Dél-Dunántúlon (8,8\%) a legalacsonyabb 2016-ban. Közép-Magyarországon és Nyugat-Dunántúlon növekedett az egyszemélyes háztartások aránya 2011-hez képest. A mutató értékének növekedése a háztartásoknak, mint a társadalom legkisebb gazdasági egységeinek az elaprózódását jelzi. Tehát Közép-Magyarországon és Nyugat-Dunántúlon nôtt az egycsaládos és az egyszemélyes háztartások aránya, míg a többcsaládos háztartásoké a két alföldi régióban.

A lakáshasználattal kapcsolatban a háztartások megoszlását vizsgáltam lakáshasználati jogcímek - tulajdonos és bérelt lakás - szerint. A tulajdonlás tekintetében az Észak-Magyarország (89,2\%), az Észak-Alföld (88,6\%) és a Dél-Alföld (88,2\%) régió szerepel a lista elején, míg a lista végén a Közép-Dunántúl (85,8\%), a Közép-Magyarország $(84,5 \%)$ és a Dél-Dunántúl (83,9 \%) áll 2016-ban. 2011-hez képest a Közép-Magyarország régió kivételével mindenhol csökkent a mutató értéke. A bérelt lakások esetében éppen fordított a helyzet 2016-ban: 2011-hez képest a Közép-Dunántúl és a Nyugat-Dunántúl kivételével minden régióban növekedett a mutató.

Ezek a mutatók tehát szoros kapcsolatban állnak az egyes régiók lakosságának jövedelmi helyzetével, valamint hatással vannak az élettel való elégedettségükre is. A következókben ezeket a mutatókat vizsgálom.

\section{A jövedelmi helyzet alakulása hazánk régióiban}

Az egy fốre jutó GDP kiszámításának célja mind az időbeli, mind a különbözô nagyságú gazdaságok közötti térbeli összehasonlítások lehetôvé tétele. Az 1. ábra az egy főre jutó bruttó hazai termék (GDP) alakulását mutatja be régiónként 2013 és 2016 között.

1. ábra: Az egy fốre jutó bruttó hazai termék alakulása régiónként (ezer Ft)

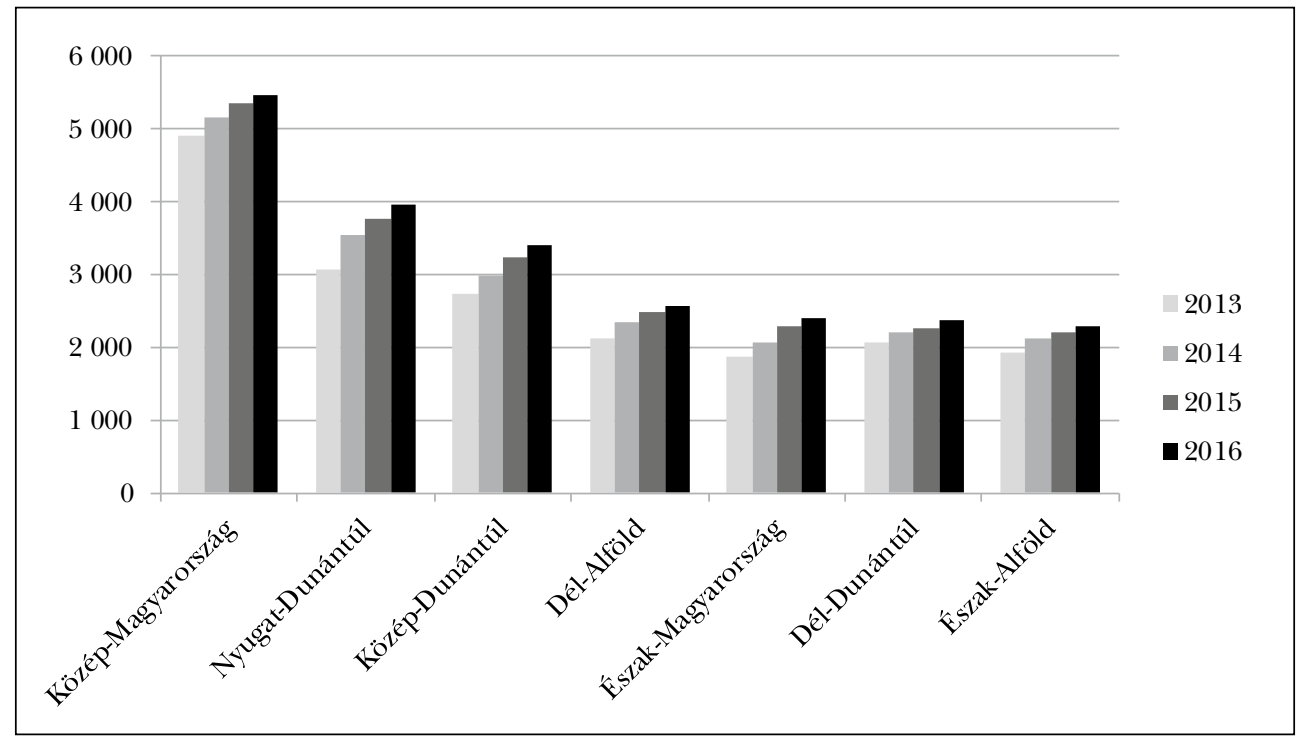

Forrás: Saját szerkesztés KSH, 2016 alapján 
A regionális adatok szerint továbbra is jelentôsek a régiók közötti különbségek Magyarországon, annak ellenére, hogy a vizsgált idôszakban kivétel nélkül évrôl évre nôtt a régiók által előállított egy fớre jutó bruttó hazai termék. A legnagyobb növekedés a Nyugat-Dunántúl régióban volt tapasztalható a vizsgált időszakban, míg a legkisebb a Dél-Dunántúl régióban. A fôvárost is magában foglaló Közép-Magyarország egy fốre jutó GDP-értéke kiemelkedóen magas (5475 ezer forint) volt a többi régióhoz képest, így jelentôs gazdasági előnyt birtokolt 2016-ban is. A legkevesebb egy főre jutó GDP-t az Észak-Alföld régió állította elô, 2298 ezer forinttal.

A háztartások jövedelmi helyzetét egyéb gazdaságpolitikai és a társadalompolitikai intézkedések mellett gyakorlatilag az ország gazdasági teljesítôképessége határozza meg. A háztartások jövedelmi helyzetében az egyes gazdasági folyamatok visszatükröződnek. Napjaink egyik releváns kérdése az, miként alakulnak a jövedelemeloszlás egyenlőtlenségei, hiszen nyilvánvaló, hogy a gazdasági növekedésbôl nem egyenlô arányban részesednek az egyes, különféle társadalmi csoportok. Mindez hatással van a területi egyenlőtlenségekre is. Hozzájárul ahhoz, hogy hol alakulnak ki a prosperáló, valamint a hátrányos helyzetú régiók, térségek (KSH, 2016).

A háztartások jövedelmi helyzete az ország különbözó régióiban jelentôsen különbözik (2. ábra). 2016-ban a legjobb helyzetben továbbra is Közép-Magyarország volt, ahol az egy fốre jutó éves átlagos nettó jövedelem 1 millió 344 ezer forint. Legkevesebb éves átlagos jövedelemmel az Észak-Alföld régióban rendelkeztek a háztartások, egy fớre vetítve 1 millió 13 ezer forinttal. A régió lemaradása kismértékben növekedett 2013-hez képest, 140 ezer forinttal. A legmarkánsabb jövedelemnövekedés a Dél-Dunántúl régióban volt tapasztalható, 248 ezer forinttal.

\section{2. ábra: A háztartások nettó jövedelmének alakulása régiónként, 2013 és 2016 között (Ft)}

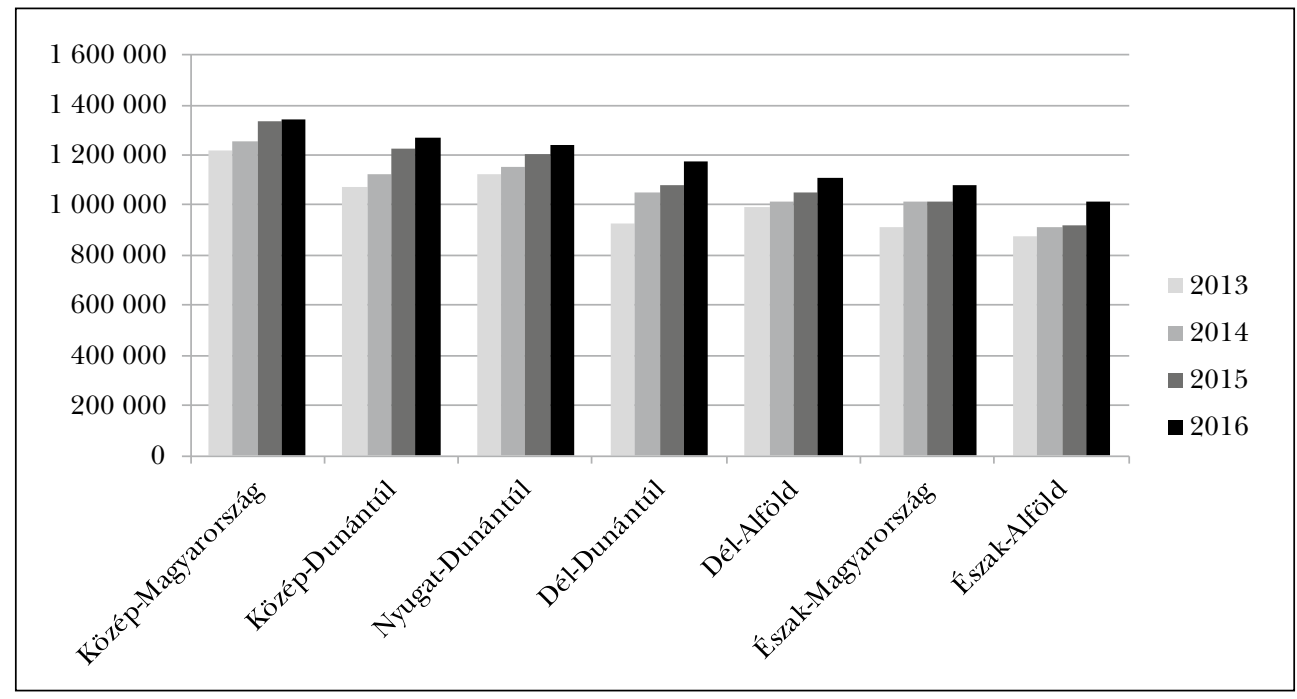

Forrás: Saját szerkesztés KSH, 2016 alapján 
Kiss Lívia Benita: A jövedelmi helyzet, az élettel való elégedettség és a környezeti...

A jövedelmi egyenlôtlenségek fontos vetületét képezik a területi egyenlőtlenségek. A következókben azt hasonlítom össze, hogy Magyarország egyes régiói milyen mértékben részesednek hazánk teljes jövedelméból, illetve népességébôl (1. táblázat). Ezeket idôsorosan vizsgálva megállapítható, hogy a népességből való részesedését tekintve Közép-Dunántúl, Nyugat-Dunántúl és Észak-Alföld stagnált, míg Pest megye, valamint Budapest súlya nôtt, a többi régió súlya szignifikánsan csökkent 2013-hoz képest. A legnagyobb mértékû részaránycsökkenés Észak-Magyarországon ment végbe. A régió 2013-ban az ország népességének 12,0\%-át tömörítette, 2015-re már csak 11,8\%-át. A jövedelmek viszonylatában a Közép-Dunántúlon és Pest megyében ment végbe a részesedések növekedése 2013 és 2015 között, míg a legnagyobb mértékú csökkenés Dél-Alföldön és Budapesten volt tapasztalható.

1. táblázat: A régiók részesedése az ország népességéból és jövedelméból (\%)

\begin{tabular}{l|c|c|c|c|c|c}
\hline \multirow{2}{*}{$\begin{array}{l}\text { Régió, Budapest, } \\
\text { Pest megye }\end{array}$} & \multicolumn{2}{|c|}{$\mathbf{2 0 1 3}$} & \multicolumn{2}{c|}{2014} & \multicolumn{2}{c}{2015} \\
\cline { 2 - 7 } & népesség & jövedelem & népesség & jövedelem & népesség & jövedelem \\
\hline Közép-Dunántúl & 10,9 & 11,2 & 10,9 & 11,2 & 10,9 & 11,4 \\
\hline Nyugat-Dunántúl & 10,0 & 11,0 & 10,0 & 10,7 & 10,0 & 11,0 \\
\hline Dél-Dunántúl & 9,3 & 8,3 & 9,3 & 8,8 & 9,2 & 8,2 \\
\hline Észak-Magyarország & 12,0 & 10,5 & 11,9 & 11,0 & 11,8 & 10,5 \\
\hline Észak-Alföld & 15,0 & 12,6 & 15,0 & 12,6 & 15,0 & 12,6 \\
\hline Dél-Alföld & 13,0 & 12,1 & 12,9 & 11,7 & 12,9 & 11,3 \\
\hline Budapest & 17,2 & 22,0 & 17,5 & 22,2 & 17,6 & 20,9 \\
\hline Pest megye & 12,5 & 12,2 & 12,5 & 11,7 & 12,6 & 14,1 \\
\hline
\end{tabular}

Forrás: Saját szerkesztés KSH, 2016 alapján

A két arányszám - népességhányad és jövedelemhányad - különbségeinek abszolút értéke jelzi a területi egyenlőtlenségek tényét: a legnagyobb inkonzisztenciák Budapesten jelentkeznek, ahol 2015-ben az ország népességének 17,6, jövedelmének 20,9\%-a összpontosult. Viszonylag jelentôs eltérés mutatkozik Észak-Alföld esetében is, de ebben a régióban a népességhányad 15\%-ával képvisel nagyobb arányt. A jövedelmekbôl való részesedés Pest megyében, valamint Nyugat- és Közép-Dunántúlon volt magasabb a népességaránynál, azonban az ország többi részében a népesség súlya a jelentôsebb.

\section{Az élettel való elégedettség alakulása hazánk régióiban}

Az élettel való általános elégedettség a szubjektív jóllét vizsgálatának kulcsváltozója (2. táblázat). A megkérdezettek egy 0-tól 10-ig terjedô skálán értékelték, hogy összességében mennyire elégedettek az életükkel $(0=$ egyáltalán nem elégedett, $10=$ teljesen elégedett). 
2. táblázat: A régiók sorrendje az élettel való elégedettség átlagértékei szerint

\begin{tabular}{l|c|c|c|c|c|c}
\hline \multirow{2}{*}{\multicolumn{1}{c|}{ Régió }} & \multicolumn{6}{c}{ Sorrend és átlagérték } \\
\cline { 2 - 8 } & \multicolumn{2}{|c|}{$\mathbf{2 0 1 6}$} & \multicolumn{2}{c}{$\mathbf{2 0 1 5}$} & \multicolumn{2}{c}{$\mathbf{2 0 1 3}$} \\
\hline Dél-Alföld & $\mathbf{1 .}$ & 6,42 & $\mathbf{3 .}$ & 6,32 & $\mathbf{2 .}$ & 6,32 \\
\hline Közép-Dunántúl & $\mathbf{2 .}$ & 6,35 & $\mathbf{1 .}$ & 6,49 & $\mathbf{2 .}$ & 6,32 \\
\hline Nyugat-Dunántúl & $\mathbf{3 .}$ & 6,21 & $\mathbf{2 .}$ & 6,38 & $\mathbf{1 .}$ & 6,38 \\
\hline Észak-Alföld & $\mathbf{4 .}$ & 6,19 & $\mathbf{4 .}$ & 6,12 & $\mathbf{4 .}$ & 6,13 \\
\hline Közép-Magyarország & $\mathbf{5 .}$ & 6,05 & $\mathbf{5 .}$ & 6,02 & $\mathbf{5 .}$ & 6,10 \\
\hline Észak-Magyarország & $\mathbf{6 .}$ & 5,77 & $\mathbf{6 .}$ & 5,79 & $\mathbf{7 .}$ & 5,90 \\
\hline Dél-Dunántúl & $\mathbf{7 .}$ & 5,67 & $\mathbf{7 .}$ & 5,75 & $\mathbf{6 .}$ & 6,03 \\
\hline
\end{tabular}

Forrás: Saját szerkesztés KSH, 2016 alapján

Az élettel való elégedettség a fiatalok (16-24) körében a legmagasabb, a 55-64 éves korcsoportig az életkor előrehaladtával jelentôsen csökken. Az életükkel elégedettebbek aránya az idôsebb generációk esetén folyamatosan csökken. A nemek szerinti átlagban a férfiak az elégedettebbek. A legmagasabb iskolai végzettség növekedésével együtt fokozatosan emelkedik az élettel való általános elégedettség szintje. A legelégedetlenebbek a legfeljebb alapfokú képzettségúek, míg a legelégedettebbek a felsőfokú végzettségúek.

Régiók szerint vizsgálva, a Dél-Alföldön élô emberek a legelégedettebbek $(6,42)$. Az országos átlagnál magasabb az elégedettség továbbá a Közép-Dunántúlon (6,35) és a Nyugat-Dunántúlon $(6,21)$, valamint az Észak-Alföldön $(6,19)$ élôk esetében. Az életükkel legkevésbé Dél-Dunántúl lakosai elégedettek $(5,67)$. A területi különbségeket a régiók eltérố társadalmi összetétele, változó településszerkezete is magyarázhatja.

\section{A jövedelmi helyzet és az élettel való elégedettség összefüggései hazánk régióiban}

A 3. táblázat a régiók rangsorát hasonlítja össze a háztartások egy fôre jutó nettó jövedelme, az egy fốre jutó GDP és az élettel való általános elégedettség szerint a vizsgált idôszakban.

A GDP és a jövedelmek alakulása egységesebb képet mutat a vizsgált idôszakban, míg az élettel való elégedettség tekintetében igencsak vegyes képet láthatunk. A GDP és a jövedelmek alakulásában Közép-Magyarország, Közép-Dunántúl és Nyugat-Dunántúl foglalta el a képzeletbeli dobogó elsô három fokát, amíg az utolsó helyek tekintetében Észak-Alföld, Dél-Dunántúl és Észak-Magyarország váltogatta egymást.

Az élettel való elégedettség alapján nem ilyen egyértelmú a helyzet. A legelégedettebb régiók a Dél-Alföld, Közép-Dunántúl és Nyugat-Dunántúl. Az elégedett kategóriába sorolható Észak-Alföld és Közép-Magyarország. Az elégedetlenebb régiók pedig a Dél-Dunántúl és Észak-Magyarország. A Dél-Alföld régiót külön is kiemelném, hiszen az egyetlen régió, ahol az elégedettség javult, míg a többi esetében stagnálást láthatunk, vagy éppen elégedetlenebb lett a lakosság. 
Kiss Lívia Benita: A jövedelmi helyzet, az élettel való elégedettség és a környezeti...

3. táblázat: A régiók rangsora GDP, jövedelmi helyzet és elégedettség szerint

\begin{tabular}{l|c|c|c|c|c|c|c|c|c}
\hline \multirow{2}{*}{\multicolumn{1}{c|}{ Régió }} & \multicolumn{3}{|c|}{ Nettó jövedelem/fó } & \multicolumn{4}{c|}{ GDP/fó } & \multicolumn{3}{c}{$\begin{array}{c}\text { Élettel való elége- } \\
\text { dettség }\end{array}$} \\
\cline { 2 - 13 } & $\mathbf{2 0 1 6}$ & $\mathbf{2 0 1 5}$ & $\mathbf{2 0 1 3}$ & $\mathbf{2 0 1 6}$ & $\mathbf{2 0 1 5}$ & $\mathbf{2 0 1 3}$ & $\mathbf{2 0 1 6}$ & $\mathbf{2 0 1 5}$ & $\mathbf{2 0 1 3}$ \\
\hline Közép-Magyarország & $\mathbf{1 .}$ & 1. & 1. & $\mathbf{1 .}$ & 1. & 1. & $\mathbf{5 .}$ & 5. & 5. \\
\hline Közép-Dunántúl & $\mathbf{2 .}$ & 2. & 3. & $\mathbf{3 .}$ & 3. & 3. & $\mathbf{2 .}$ & 1. & 2. \\
\hline Nyugat-Dunántúl & $\mathbf{3 .}$ & 3. & 2. & $\mathbf{2 .}$ & 2. & 2. & $\mathbf{3 .}$ & 2. & 1. \\
\hline Dél-Dunántúl & $\mathbf{4 .}$ & 4. & 5. & $\mathbf{6 .}$ & 6. & 5. & $\mathbf{7 .}$ & 7. & 6. \\
\hline Dél-Alföld & $\mathbf{5 .}$ & 5. & 4. & $\mathbf{4 .}$ & 4. & 4. & $\mathbf{1 .}$ & 3. & 2. \\
\hline Észak-Magyarország & $\mathbf{6 .}$ & 6. & 6. & $\mathbf{5 .}$ & 5. & 7. & $\mathbf{6 .}$ & 6. & 7. \\
\hline Észak-Alföld & $\mathbf{7 .}$ & 7. & 7. & $\mathbf{7 .}$ & 7. & 6. & $\mathbf{4 .}$ & 4. & 4. \\
\hline
\end{tabular}

Forrás: Saját szerkesztés KSH, 2016 alapján

Ha a jövedelem és az elégedettség rangsorát összevetjük, látható, hogy a jövedelmek tekintetében elsố helyen álló Közép-Magyarország az elégedettségi sorban csupán az 5. helyet foglalta el. Közép-Dunántúl és Nyugat-Dunántúl a 2. és 3. jövedelmi pozíciójához ugyanezek az elégedettségi rangok tartoznak. A 4. helyen lévô Dél-Dunántúl a legelégedetlenebb volt a sorban, ugyanakkor az 5. helyen álló Dél-Alföld viszont a legelégedettebb volt. Észak-Magyarország jövedelem és elégedettség tekintetében is a 6 . helyen állt. Észak-Alföld zárta a sort a jövedelmek esetében, de az elégedettségi sorban a 4 . helyet birtokolta.

Az egy fốre jutó GDP és az elégedettség viszonyából látható, hogy kicsit változott a kép az elốzô összevetéshez képest. Nyugat-Dunántúl egy fốre jutó GDP-je a 2. helyet hozta a régió számára, ami hasonló elégedettségi eredménnyel párosult. Dél-Alföld, Észak-Magyarország szintén eloorelépett a GDP sorában, míg a Dél-Dunántúl a 6. helyre csúszott vissza. Az Észak-Alföld régió az egy fốre jutó GDP tekintetében is az utolsó helyre került.

\section{Hazánk régióinak környezeti terhelése}

A környezeti terhelésekhez kapcsolódóan megnéztem, hogyan alakult a szennyvíz- és hulladékgyújtés mérésére vonatkozó mutatószámok alakulása. 2013-as állapotot tükrözô térkép szerint a közüzemi szennyvízhálózatba a legtöbb lakás a Közép-Magyarország régióból $(87,1 \%)$ kapcsolódott be, míg a legkevesebb a Dél-Alföld régióból (58,4\%), amiból az összes biológiailag vagy III. tisztítási fokozattal tisztított szennyvíz (3. ábra).

A 4. ábra a közszolgáltatás keretében elszállított hulladékmennyiséget szemlélteti régiónként, 2013 és 2016 között. A közszolgáltatás keretében a Közép-Magyarország régióból közel 4 millió tonna hulladékot szállítottak ebben az idôszakban. A többi régióban a két alföldi - Észak- és Dél-Alföld - kivételével közel azonos mennyiséget (1 millió 200 ezer tonna körül) szállítottak el a közszolgáltatás keretében, az Észak-Alföld és a Dél-Alföld régióban pedig 1 millió 500 ezer tonnát. 
3. ábra: A közüzemi szennyvízgyújtó hálózatba bekapcsolt lakás a lakásállomány \%-ában, régiónként, 2013-ban

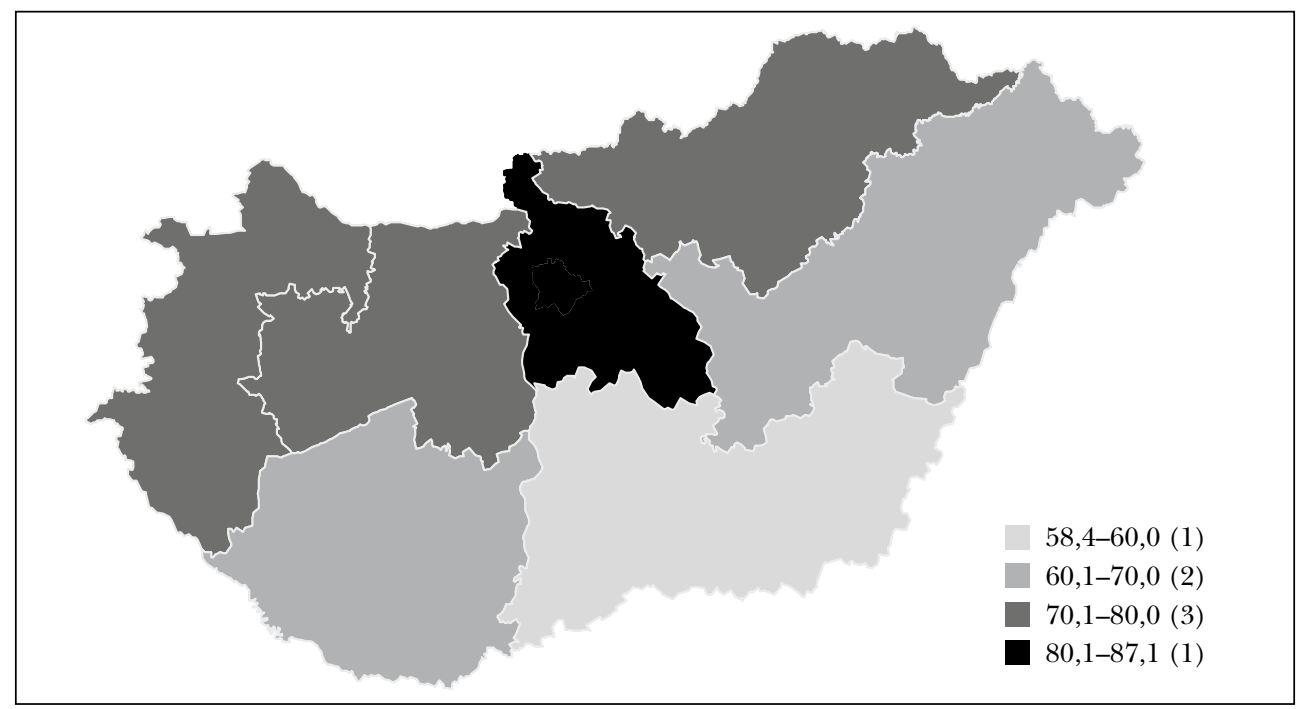

Forrás: KSH interaktív térkép

A Dél-Dunántúl és a Dél-Alföld kiemelkedik az elkülönített gyújtéssel elszállított hulladék tekintetében, hiszen az összes hulladék 7,9 és 7,8\%-át elkülönített gyújtéssel szállították el a vizsgált idôszakban. Az Észak-Magyarország régióban azonban mindössze 2,9\%-át szállították el a hulladéknak elkülönített gyújtéssel, ami nagyon alacsonynak mondható.

\section{4. ábra: A közszolgáltatás keretében elszállitott hulladék régiónként (ezer tonna)}

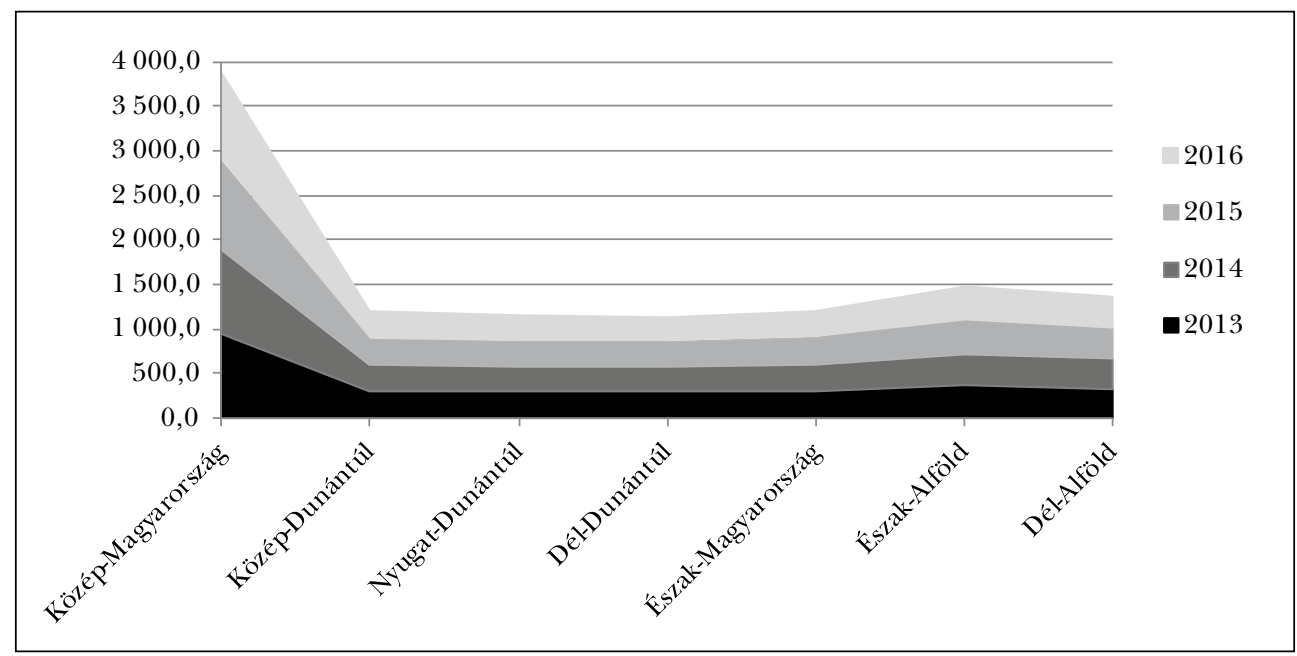

Forrás: Saját szerkesztés KSH, 2016 alapján 
Kiss Lívia Benita: A jövedelmi helyzet, az élettel való elégedettség és a környezeti...

\section{ÖSSZEFOGLALÁS}

A régiók jövedelmi helyzete a vizsgált idôszakban kivétel nélkül folyamatos javulást mutatott. 2016-ban a Közép-Magyarország régióban jut a legtöbb éves jövedelem egy fớre vetítve, míg Észak-Alföldön a legkevesebb. A legmarkánsabb jövedelemnövekedés a Dél-Dunántúl régióban volt tapasztalható a vizsgált idôszakban.

A régiók az egy fớre jutó GDP előállításában is szintén kivétel nélküli folyamatos javulást mutattak a vizsgált idôszakban. 2016-ban a Közép-Magyarország régióban jutott egy fớre a legmagasabb GDP-érték, míg Észak-Alföldön volt a legalacsonyabb. A legjelentősebb növekedés a Nyugat-Dunántúl régióban látható.

Az élettel való elégedettségrôl elmondható, hogy elég vegyes képet mutat. A jövedelmi helyzetben 5. helyet elfoglaló Dél-Alföld lakossága volt a legelégedettebb az élettel 2016-ban, míg a jövedelem alapján az elsô helyen szereplő Közép-Magyarország az élettel való elégedettség rangsorában csak az 5. helyet foglalja el. A Dél-Alföld régiót külön is kiemelném, hiszen az egyetlen régió, ahol az elégedettség javult, míg a többi esetében stagnálást láthattunk, vagy éppen elégedetlenebb lett a lakosság.

A társadalmi haladás mutatószámai közül az egészségesen várható élettartam esetében a várakozásokhoz híven Közép-Magyarországon a legmagasabb a mutató, míg Észak-Alföldön a legalacsonyabb, amit az életkörülmények magyarázhatnak. Az életkörülmények jelentôsen függnek a jövedelmi helyzettől, hiszen a leggazdagabb régió lakosságának a legmagasabb a várható élettartama, ugyanakkor a legszegényebb régióban a legalacsonyabb. A háztartások lakáshasználati jogcímek - tulajdon és bérlet - szerinti megoszlása érdekes képet mutat. Azt gondolnánk, hogy a leggazdagabb régiókban a legmagasabb a tulajdon alapján történô megoszlása a háztartásoknak, ezzel ellentétben mégis a legszegényebb régiókban, Észak-Magyarországon és Észak-Alföldön. Ugyanakkor a lakásbérlet megoszlása Közép-Magyarországon a legmagasabb, míg a legalacsonyabb az Észak-Alföldön. Ezt azzal lehet magyarázni, hogy Közép-Magyarországon jóval drágábban lehet saját tulajdonú lakáshoz jutni, mint vidéken. Emellett a magasabb fizetés reményében a szegényebb régiókból érkezô munkavállalók nem rendelkeznek annyi megtakarítással, hogy saját tulajdonú házhoz jussanak, így csak a lakásbérlet jöhet szóba náluk. Mindemellett meghatározó lehet az is, hogy milyen az adott régió háztartás-összetétele, vagyis az egycsaládos, a többcsaládos és az egyszemélyes háztartások aránya miként alakul. Közép-Magyarországon, a leggazdagabb régióban az egyszemélyes háztartás jellemzô, míg a legszegényebb Észak-Alföldön a többcsaládos háztartás. Szintén a jövedelmi helyzettel magyarázható, hogy az egyes régiók háztartásaiban mennyien élnek együtt. A szegényebb régiók esetében tehát egy háztartásban több család (generáció) él együtt, hiszen jövedelmi helyzetük nem teszi lehetôvé, hogy önálló háztartást vezessenek. Összességében ezek a mutatók a jövedelmi helyzet függvényében alakulnak, és nyilvánvalóan belátható, hogy hatással vannak az élettel való elégedettségre.

A régiók idôsoros adatai arról árulkodnak, hogy a folyamatos és jelentôs gazdasági fejlődés egyáltalán nem társult az elégedettség, a szubjektív jóllét növekedésével, hiszen hiába növekedett folyamatosan a régiók jövedelmi helyzete, az élettel való elé- 
gedettségük viszont inkább stagnált vagy csökkent. A Dél-Dunántúli régió, ahol a legjelentôsebb volt a vizsgált idôszakban az egy fớre vetített éves jövedelem növekedése, utolsó helyen állt az élettel való elégedettség sorában. Közép-Magyarország, mint a legfejlettebb régió, csak az 5. helyen állt az elégedettség rangsorában, míg a gazdaságilag elmaradott Észak-Alföldi régió a 4. helyen. Tehát a legfejlettebb régió nem a legelégedettebb, ugyanakkor a leginkább elmaradott régió az elégedettség tekintetében a középmezónybe tartozik.

A közüzemi szennyvízhálózatba a legtöbb lakás a Közép-Magyarország régióból kapcsolódott be, míg a legkevesebb a Dél-Alföld régióból. A közüzemi szennyvízgyújtố hálózatba bekapcsolt lakásállomány esetében elófordul a 30\%-os különbség is az egyes régiók között, ami rendkívül jelentôs. Kedvezó azonban, hogy az összes biológiailag vagy III. tisztítási fokozattal tisztított szennyvíz.

A közszolgáltatás keretében a Közép-Magyarország régióból szállították el a legtöbb hulladékot. A többi régióból közel azonos mennyiséget szállítottak el, kivéve a két alföldit - Észak- és Dél-Alföld -, ahonnan kicsivel többet. A Dél-Dunántúl és a Dél-Alföld kiemelkedik az elkülönített gyújtéssel elszállított hulladék tekintetében.

Tehát a környezeti állapot elég változatos, ugyanakkor kedvezôtlen képet mutat az egyes régiók tekintetében, ami magában hordozza a felszíni és felszín alatti vizeink, valamint a talajszennyezés kockázatát. Érdekes, hogy az elmaradott Észak-Magyarország és Dél-Dunántúl csatornázottsága is meghaladja a fejlettebb dél-alföldiét. Közép-Magyarország termeli a legtöbb hulladékot, ami nem okoz meglepetést, míg legkevesebbet a Dél-Dunántúl. Ebben az esetben is érdekes, hogy az elkülönített hulladékgyújtés tekintetében az elmaradott Dél-Dunántúl emelkedik ki, holott azt gondolnánk, hogy a fejlettségi rangsor élén álló Közép-Magyarországnak kellene ezt a posztot betöltenie.

\section{FELHASZNÁLT IRODALOM}

Blanchflower, David G. - Oswald, Andrew J. (2004): Well-Being Over Time in Britain and the USA. Journal of Public Economics, Vol. 88, No. 7-8, 1359-1386, https://doi.org/10.1016/s0047-2727(02)00168-8.

Boyce, Christopher J. - Wood, Alex M. (2011): Personality and the Marginal Utility of Income: Personality Interacts With Increases in Household Income to Determine Life Satisfaction. Journal of Economic Behavior and Organization, Vol. 78, No. 1-2, 183-191, https://doi.org/10.1016/j.jebo.2011.01.004.

Budria, Santi - Ferrer-i-Carbonell, Ada (2012): Income Comparisons and Non-Cognitive Skills. SOEPpaper, No. 441., http://dx.doi.org/10.2139/ssrn.2046976.

Clark, Andrew E. - Frijters, Paul - Shields, Michael A. (2008): Relative Income, Happiness, and Utility: An Explanation for the Easterlin Paradox and Other Puzzles. Journal of Economic Literature, Vol. 46, No. 1, 95-144, https://doi.org/10.1257/jel.46.1.95.

Diener, Ed - Lucas, Richard E. - Schimmack, Ulrich - Helliwell, John F. (2009): Well-Being for Public Policy. Oxford University Press, New York, https://doi.org/10.1093/acprof:oso/9780195334074.001.0001.

Diener, Ed - Kahneman, Daniel - Tov, William - Arora, Raksha (2010): Income's Association With Judgements of Life Versus Feelings. In: Ed Diener - John Helliwell - Daniel Kahneman (eds.): International Differencies in Well-Being. Oxford University Press, New York, https://doi.org/10.1093/acprof:oso/9780199732739.003.0001.

Diener, Ed - Ng, Weiting - Harter, James - Arora, Raksha (2010): Wealth and Happiness Across the world: Material prosperity Predicts Life Evaluation, Whereas Psychosocial Prosperity Predicts Positive Feeling. Journal of Personality and Social Psychology, Vol. 99, No. 1, 52-61, https://doi.org/10.1037/a0018066. 
Kiss Lívia Benita: A jövedelmi helyzet, az élettel való elégedettség és a környezeti...

Easterlin, Richard A. (1973): Does Money Buy Happiness? Public Interest, No. 30, 3-10.

Easterlin, Richard A. (1974): Does Economic Growth Improve the Human Lot? Some Empirical Evidence. In: Paul A. David - Melvin W. Reder (eds.): Nations and Households in Economic Growth. Academic Press, New York.

Easterlin, Richard A. (1995): Will Raising the Incomes of all Increase the Happiness of All? Journal of Economic Behavior and Organization, Vol. 27, No. 1, 35-47, https://doi.org/10.1016/0167-2681 (95)00003-B.

Easterlin, Richard A. - Angelescu, Laura (2009): Happiness and Growth the World Over: Time Series Evidence on the Happiness-Income Paradox. IZA Discussion Paper, No. 4060.

Easterlin, Richard A. - Angelescu McVey, Laura - Switek, Malgorzata - Sawangfa, Onnicha - Smith Zweig, Jacqueline (2010): The Happiness-Income Paradox Revisited. PNAS, Vol. 107, No. 52, 22463-22468, https://doi.org/10.1073/pnas.1015962107.

Easterlin, Richard A. (2013): Happiness, Growth, and Public Policy. Economic Inquiry, Vol. 51, No. 1, 1-15, https://doi.org/10.1111/j.1465-7295.2012.00505.x.

Frey, Bruno S. - Stutzer, Alois (2002): Happiness and Economics: How the Economy and Institutions Affect Human Well-Being. Princeton University Press, Princeton and Oxford.

Fromann Richárd (2011): Nemzetek boldogsága és annak forrása az Easterlin-paradoxon tükrében. In: Prazsák Gergô (szerk.): Nemzetek Európában. ELTE TáTK Szociológia Doktori Iskola, Budapest, http:// tatk.elte.hu/szakmaimegjelenesek?id=NW-136 (Letöltés: 2018. január 20.).

Gébert Judit (2012): A jólét mérésének elméleti alapjai és problémái. In: Bajmócy Zoltán - Lengyel Imre - Málovics György (szerk.): Regionális innovációs képesség, versenyképesség és fenntarthatóság. JATEPress, Szeged.

Hajdu Tamás (2015): Tanulmányok a szubjektív jóllét és az anyagi helyzet kapcsolatáról: jövedelem, fogyasztás és egyenlôtlenség. PhD-értekezés, Budapesti Corvinus Egyetem Közgazdaságtani Doktori Iskola, Budapest, https://doi.org/10.14267/phd.2016001.

Hajdu Tamás - Hajdu Gábor (2013): Jövedelem és szubjektív jóllét: az elemzési módszer megválasztásának hatása a levonható következtetésekre. Statisztikai Szemle, 91. évf., 11. sz., 1046-1071.

KSH (2014a): Környezeti helyzetkép, 2013. Központi Statisztikai Hivatal, Budapest.

KSH (2014b): A jóllét magyarországi indikátorrendszere, 2013. Központi Statisztikai Hivatal, Budapest.

KSH (2014c): Érdekességek a szubjektív jóllét (well-being) magyarországi vizsgálatából. Statisztikai Tükör, 8. évf., 2. sz., 1-4.

KSH (2016): A háztartások életszínvonala, 2015. Központi Statisztikai Hivatal, Budapest.

Layard, Richard - Mayraz, Guy - Nickell, Stephen J. (2008): The Marginal Utility of Income. Journal of Public Economics, Vol. 92, No. 8-9, 1846-1857, https://doi.org/10.1016/j.jpubeco.2008.01.007.

Nordenfelt, Lennart (1993): Quality of Life, Health and Happiness. Ashgate Publishing.

OECD (2013): OECD Guidelines on Measuring Subjective Well-being. OECD Publishing, Paris, https://doi. org/10.1787/9789264191655-7-en.

Sacks, Daniel W. - Stevenson, Betsey - Wolfers, Justin (2012): The New Stylized Facts aAbout Income and Subjective Well-Being. Emotion, Vol. 12, No. 6, 1181-1187, https://doi.org/10.1037/a0029873.

Scitovsky Tibor (1990): Az örömtelen gazdaság. Közgazdasági és Jogi Könyvkiadó, Budapest.

Stevenson, Betsey - Wolfers, Justin (2008): Economic Growth and Subjective Well-Being: Reassessing the Easterlin Paradox. Brookings Papers on Economic Activity, Vol. 39, No. 1, 1-8,. https://doi.org/10.1353/ eca.0.0001.

Stiglitz, Joseph E. - Sen, Amartya - Fitoussi, Jean-Paul (2010): A Bizottság jelentése a gazdasági teljesítmény és a társadalmi fejlôdés mérésérôl. Statisztikai Szemle, 88. évf., 3. sz., 305-320.

Veenhoven, Ruut - Vergunst, Floris (2013): The Easterlin Illusion. Economic Growth Does Go With Greater Happiness. EHERO Working Paper, No. 1, 1-49. 